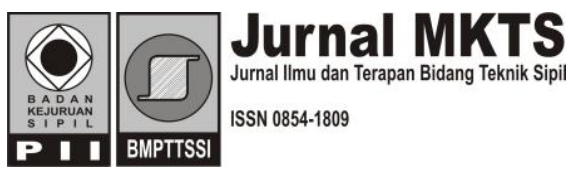

\title{
Analisis Prioritas Pembangunan Embung Metode Cluster Analysis, AHP dan Weighted Average (Studi Kasus: Embung di Kabupaten Semarang)
}

\author{
Bima Anjasmoro \\ Bidang Sumber Daya Air \\ Balai Besar Wilayah Sungai Pemali Juana (BBWS PJ) \\ Jl. Brigjend. S. Sudiarto No. 375 Semarang \\ E-mail:bima3207@gmail.com
}

Suharyanto

Jurusan Teknik Sipil, Fakultas Teknik, Universitas Diponegoro

Jl.Prof. Soedarto, SH, Tembalang, Semarang 50275

E-mail: suharyanto20@yahoo.co.id

Sri Sangkawati

Jurusan Teknik Sipil, Fakultas Teknik, Universitas Diponegoro

Jl.Prof. Soedarto, SH, Tembalang, Semarang 50275

E-mail: srisangkawati@gmail.com

\begin{abstract}
The Feasibility study potential of small dams in Semarang District has identified 8 (eight) urgent potential small dams. These potential dams here to be constructed within 5 (five) years in order to overcome the problem of water shortage in the district. However, the government has limited funding source. It is necessary to select the more urgent small dams to be constructed within the limited budget. The purpose of the research is determining the priority of small dams construction in Semarang District. The method used to determine the priority in this study is cluster analysis, AHP and weighted average method. The criteria used to determine the priority in this study consist of: vegetation in the inundated area, volume of embankment, land acquisition area, useful storage, recervoir life time, water cost $/ \mathrm{m}^{3}$, access road to the dam site, land status at abutment and inundated area, construction cost, operation and maintenance cost, irrigation service area and raw water benefit. Based on results of cluster analysis, AHP and weighted average method can be conclude that the priority of small dams construction is 1) Mluweh Small Dam (0.165), 2) Pakis Small Dam (0.142), 3) Lebak Small Dam (0.134), 4) Dadapayam Small Dam (0.128), 5) Gogodalem Small Dam (0.119), 6) Kandangan Small Dam (0.114), 7) Ngrawan Small Dam (0.102) and 8) Jatikurung Small Dam (0.096). Based on analysis of the order of priority of 3 (three) method showed that method is more detail than cluster analysis method and weighted average method, because the result of AHP method is closer to the conditions of each dam in the field.
\end{abstract}

Keywords: AHP, Cluster analysis, Priority dam, Weighted average.

\begin{abstract}
Abstrak
Dalam Studi Kelayakan Potensi Embung di Kabupaten Semarang telah diidentifikasi 8 calon embung jangka pendek. Sehubungan dengan banyaknya calon embung yang teridentifikasi dan dengan keterbatasan biaya, tidak semuanya bisa dibangun dalam pembangunan 5 (lima) tahun anggaran. Oleh sebab itu perlu disusun prioritas pembangunan embung. Metode yang digunakan untuk menentukan embung prioritas adalah analysis cluster, AHP dan weighted average. Kriteria yang digunakan dalam penentuan prioritas terdiri dari vegetasi area genangan, volume material timbunan, luas daerah yang akan dibebaskan, volume tampungan efektif, lama operasi, harga air $/ \mathrm{m}^{3}$, akses jalan masuk menuju site bendungan, status lahan di site dan
\end{abstract}


genangan, biaya konstruksi embung, biaya operasi dan pemeliharaan, cakupan daerah irigasi dan manfaat air baku. Berdasarkan hasil analisa metode cluster analysis, AHP dan weighted average, dapat disimpulkan prioritas pembangunan embung adalah: 1) Embung Mluweh (0,165), 2) Embung Pakis (0,142), 3) Embung Lebak (0,134), 4) Embung Dadapayam (0,128), 5) Embung Gogodalem (0,119), 6) Embung Kandangan (0,114), 7) Embung Ngrawan (0,102) dan 8) Embung Jatikurung (0,096). 3) Dari ke 3 (tiga) metode tersebut menunjukan bahwa metode AHP lebih detail dari pada metode cluster analysis dan metode weighted average. Hal ini dapat terlihat dari hasil metode AHP yang lebih mendekati kondisi masing-masing embung di lapangan.

Kata-kata Kunci: AHP, Cluster analysis, Embung prioritas, Weighted average.

\section{Pendahuluan}

Air merupakan zat kehidupan, dimana tidak satupun mahluk hidup di planet bumi ini yang tidak membutuhkan air. Hasil penelitian menunjukkan bahwa 65 - 75\% dari berat badan manusia dewasa terdiri dari air. Menurut ilmu kesehatan, setiap orang memerlukan minum sebanyak 2,5-3 liter setiap hari termasuk air yang berada dalam makanan. Manusia bisa bertahan hidup 2-3 minggu tanpa makan, tapi hanya bisa bertahan hidup 2-3 hari tanpa air minum (Suripin, 2001).

Hanya 2,53\% air di bumi kita yang berupa air tawar dan dari $2,53 \%$ hanya $39,526 \%$ yg dapat dimanfaatkan dengan biaya rendah, yaitu: air di danau, sungai, waduk dan sumber air tanah dangkal. Sehingga diperlukan upaya bersama untuk mempertahankan keberadaannya demi kelangsungan kehidupan, peradaban sekarang dan yang akan datang (Kodoatie, 2004).

Permasalahan pengelolaan sumber daya air salah satunya adalah perilaku manusia guna mencukupi kebutuhan hidup yaitu perubahan tata guna lahan untuk keperluan mencari nafkah dan tempat tinggal. Perubahan tata guna lahan berpengaruh terhadap ketersediaan dan kebutuhan air. Sebagai contoh ketika suatu kawasan hutan berubah menjadi pemukiman, maka kebutuhan air meningkat karena dipakai untuk penduduk di pemukiman tersebut. Sebagai akibatnya ketersediaan air berkurang karena daerah resapan air berkurang. Ketika lahan berubah maka terjadi peningkatan debit aliran permukaan. Akibatnya di daerah hilir mendapatkan debit yang berlebih dan dampaknya terjadi banjir. Ketika lahan berubah maka kapasitas resapan hilang sehingga bencana kekeringan meningkat di musim kemarau.

Dengan tingginya fluktuasi potensi SDA antara musim hujan dan musim kemarau merupakan salah satu bentuk gejala menurunnya daerah resapan air di wilayah ini baik dari segi luasannya maupun fungsinya. Hal ini disebabkan oleh terjadinya peningkatan alih fungsi lahan di daerah resapan untuk keperluan pengembangan fisik prasarana, pemukiman, perindustrian dan lahan usaha pertanian masyarakat yang kurang mempertimbangkan kelestarian lingkungan dan kurangnya kesadaran masyarakat terhadap dampak yang ditimbulkan.

Beberapa permasalahan air tersebut menunjukkan betapa pentingnya untuk mengelola dan melakukan pengembangan sumber daya air dengan baik sehingga dapat menunjang kehidupan masyarakat dengan baik. Salah satu wilayah kabupaten yang memerlukan pengembangan lebih lanjut dan akan dibahas dalam studi ini adalah Kabupaten Semarang. Kabupaten Semarang terletak di Kota Semarang dan merupakan daerah dengan kemiringan cukup landai dimana wilayah Kabupaten Semarang memiliki sumber daya air permukaan yang melimpah.

Dalam Laporan Tahunan Balai Besar Wilayah Sungai Pemali Juana berupa Studi Kelayakan Potensi Embung-Waduk Kabupaten Semarang telah teridentifikasi 8 calon embung prioritas jangka pendek (Gambar 1). Embung tersebut di antaranya adalah Embung Dadapayam, Mluweh, Lebak, Pakis, Jatikurung, Gogodalem, Kandangan dan Ngrawan yang pada dasarnya semua embung bermanfaat untuk manusia karena embung merupakan penampung air yang berfungsi untuk irigasi, air baku, industri, dan lain-lain, akan tetapi, pemerintah tidak mungkin membangun semua embung tersebut karena masalah keterbatasan finansial, sehingga pemerintah harus menentukan prioritas dari embung-embung tersebut.

Penelitian ini untuk menentukan urutan pembangunan embung jangka pendek Di Kabupaten Semarang yang berdaya guna paling efektif dan yang paling efisien.

Lokasi penelitian ini berada di wilayah administratif Kabupaten Semarang, Provinsi Jawa Tengah. Kabupaten Semarang dengan ibukota Kabupatennya Ungaran, terletak di wilayah Provinsi Jawa Tengah dan secara geografis berada pada posisi diantara:

- $110^{\circ} 14^{\prime} 55^{\prime \prime}, 110^{\circ} 39^{\prime} 03^{\prime \prime}$ BT

- 7०3'57' - $7^{\circ} 30^{\prime} 00^{\prime \prime}$ LS. 


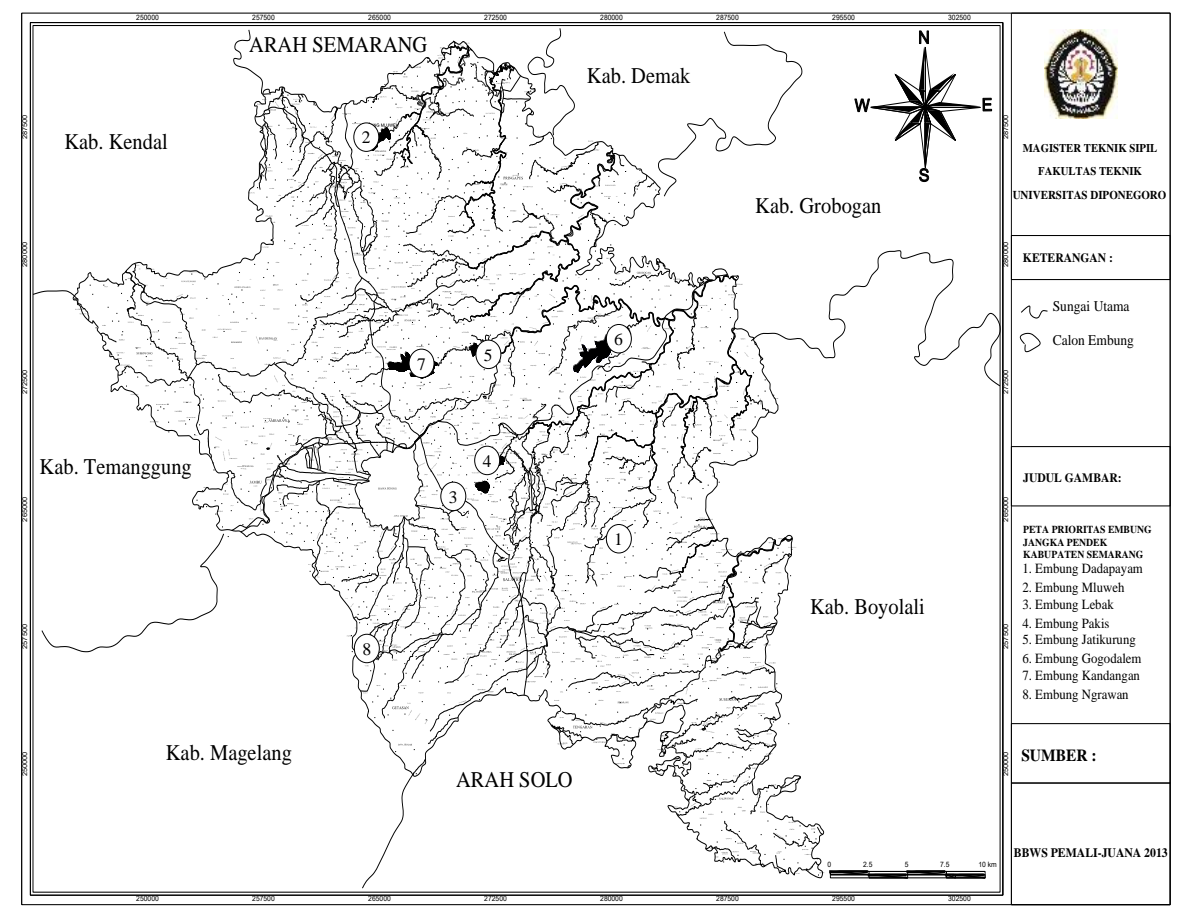

Gambar 1. Peta lokasi embung di Kabupaten Semarang

Luas wilayah Kabupaten Semarang adalah 95.020,674 ha. Luas tersebut menempati 2,92\% luas wilayah Provinsi Jawa Tengah. Secara administratif, wilayah Kabupaten Semarang memiliki batas-batas wilayah sebagai berikut:

- Sebelah Utara : Kota Semarang dan Kabupaten Demak

- Sebelah Timur : Kabupaten Boyolali dan Kabupaten Grobogan

- Sebelah Selatan : Kabupaten Boyolali dan Kabupaten Magelang

- Sebelah Barat : Kabupaten Temanggung dan Kabupaten Kendal

- Bagian tengah : Kota Salatiga.

Embung adalah sebutan lain untuk bendungan kecil. Bendungan kecil adalah bendungan yang tidak memenuhi syarat-syarat sebagai bendungan besar. (Soedibyo, 1993)

Menurut International Commission on Large Dams (ICOLD) definisi bendungan kecil/embung adalah:

1. Bendungan yang tingginya kurang dari $15 \mathrm{~m}$, diukur dari bagian terbawah pondasi sampai ke puncak bendungan.

2. Bendungan yang tingginya antara 10-15 m disebut bendungan kecil/embung apabila memenuhi beberapa kriteria sebagai berikut:

a. Panjang puncak bendungan kurang dari $500 \mathrm{~m}$ b. Kapasitas waduk yang terbentuk kurang dari 1 juta $\mathrm{m}^{3}$

c. Debit banjir maksimal yang diperhitungkan kurang dari $2000 \mathrm{~m}^{3} /$ detik

d. Bendungan tidak menghadapi kesulitankesulitan khusus pada pondasinya

e. Bendungan didesain seperti biasanya

Prioritas pembangunan embung adalah penentuan urutan pembangunan embung dari beberapa embung dengan tujuan untuk memilih urutan embung yang berdaya guna paling efektif dan efisien. Di dalam proses pemilihan embung, aspek teknik dan non teknik sering dipakai dalam menganalisa proses pemilihannya.

\section{Metode Penelitian}

Berdasarkan pedoman peraturan yang telah diketahui dari beberapa variabel yang berkaitan dalam pembangunan embung dan beberapa alternatif embung yang sudah ada akan dianalisa dengan metode cluster analysis metode non hierarki, dimana data yang diambil adalah data sekunder berupa data teknik dari masing-masing embung. Tujuan dari analisis cluster dalam penelitian ini adalah sebagai penentuan prioritas pembangunan embung dan sebagai penentuan variabel-variabel yang berpengaruh dalam menentukan embung prioritas dengan pengujian hipotesis melalui validasi cluster. Dengan melihat tabel Anova dapat diketahui variabel-variabel yang telah membentuk cluster yang merupakan variabel 
yang berpengaruh dalam penentuan embung prioritas.

Langkah selanjutnya adalah analisa prioritas pembangunan embung dengan Metode Analytical Hierarchy Process AHP data kuesioner, data teknik dan metode weighted average yang diawali dengan penyusunan hierarki yaitu dengan menentukan tujuan, kriteria dan alternatif. Alur penelitian dapat dilihat pada Gambar 2.

\section{Metode cluster analysis}

Cluster analysis adalah analisis untuk mengelompokkan elemen yang mirip sebagai objek penelitian untuk menjadi kelompok (cluster) yang berbeda.

Analisis cluster berguna untuk meringkas data dengan jalan mengelompokkan objek-objek berdasarkan kesamaan karakteristik tertentu diantara objek-objek yang akan diteliti. Analisis cluster terbagi atas 2 metode, yaitu metode hierarki dan non-hierarki.

Pada metode non-hirarki, digunakan jarak euclidian, untuk menetapkan nilai kedekatan antara objek. Bakal cluster pertama adalah observasi pertama dalam set data. Bakal kedua adalah observasi lengkap berikutnya yang dipisahkan dari bakal pertama oleh jarak minimum khusus.

Analisis cluster adalah suatu alat untuk mengelompokkan sejumlah $n$ objek berdasarkan $p$ variabel yang secara relatif mempunyai kesamaan karakteristik diantara objek-objek tersebut, sehingga keragaman dalam suatu kelompok tersebut lebih kecil dibandingkan dengan keragaman antar kelompok. Objeknya dapat berupa barang, jasa, hewan, manusia (responden, konsumen, atau yang lain). Objek tersebut akan diklasifikasikan dalam satu atau lebih cluster sehingga objek-objek yang berada dalam satu cluster akan mempunyai kemiripan atau kesamaan karakter.

Konsep dasar dalam cluster analysis adalah sebagai berikut:

1. Menentukan ukuran ketakmiripan antara kedua objek.

Proses pertama yaitu mengukur seberapa jauh ada kesamaan antar objek. Dengan memiliki sebuah ukuran kuantitatif untuk mengatakan dua objek tertentu lebih mirip dibandingkan dengan objek lain, akan mempermudah proses pengclusteran. Salah satu yang bisa menjadi ukuran ketidakmiripan adalah fungsi jarak (similaritas) antara objek a dan b, yang biasa dinotasikan dengan $d(a, b)$. Adapun sifat-sifat ukuran ketidakmiripan adalah: $\mathrm{d}(\mathrm{a}, \mathrm{b})>0$; d $(\mathrm{a}, \mathrm{b})=0 ; \mathrm{d}(\mathrm{a}, \mathrm{b})=\mathrm{d}(\mathrm{b}, \mathrm{a}) ;(\mathrm{a}, \mathrm{b})$ meningkat seiring semakin tidak miripnya kedua objek a dan b; d $(a, c) \leq d(a, b)+d(b, c)$.

Jarak paling umum digunakan adalah jarak euclidian. Ukuran jarak atau ketidaksamaan antar objek $k e-i$ dengan objek $k e-j$, dapat disimbolkan dengan $d_{i j}$. Adapun nilai $d_{i j}$ diperoleh melalui perhitungan jarak kuadrat sebagai berikut:

$d_{i j}=\sqrt{\sum_{k-1}^{p}\left\{x_{i k}-x_{j k}\right\}}$

dimana:

$d_{i j}=$ jarak kuadrat euclidian antar objek ke-i dengan objek ke-j

$p=$ jumlah variabel cluster

$x_{i k}=$ nilai dari objek ke-i pada variabel ke-k

$x_{j k}=$ nilai dari objek ke-j pada variabel ke-k

\section{Membuat cluster metode non-hierarki}

Metode ini dimulai dengan proses penentuan jumlah gerombol terlebih dahulu, dan yang digunakan adalah metode $k$-means. Metode $k$ means digunakan sebagai alternatif metode cluster untuk data dengan ukuran yang besar karena memiliki kecepatan yang lebih tinggi dibandingkan metode hierarki.

Mac Queen menyarankan bahwa penggunaan $k$ means untuk menjelaskan algoritma dalam penentuan suatu objek ke dalam cluster tertentu berdasarkan rataan terdekat. Proses pengelompokan dengan $k$-means adalah:

- Menentukan besarnya $k$, yaitu banyaknya cluster dan menentukan centroid (rata-rata) di tiap cluster.

- Menghitung jarak tiap objek dengan setiap centroid.

- Menghitung kembali rataan (centroid) untuk cluster yang baru terbentuk.

- Mengulangi langkah 2 sampai tidak ada lagi pemindahan objek antar cluster.

\section{Metode AHP}

Menurut Saaty, 1993, proses pengambilan keputusan pada dasarnya adalah memilih suatu alternatif. Peralatan utama AHP adalah sebuah hirarki fungsional dengan input utamanya persepsi manusia. Dengan hirarki, suatu masalah kompleks dan tidak terstruktur dipecahkan ke dalam kelompok-kelompoknya dan kemudian kelompok- 
kelompok tersebut diatur menjadi suatu bentuk hirarki.

Pada dasarnya langkah-langkah dalam metode AHP meliputi:

1) Mendefinisikan masalah dan menentukan solusi yang diinginkan.

2) Membuat struktur hirarki yang diawali dengan tujuan umum, dilanjutkan dengan subtujuansubtujuan, kriteria dan kemungkinan alternatifalternatif pada tingkatan kriteria yang paling bawah.

3) Membuat matriks perbandingan berpasangan yang menggambarkan kontribusi relatif atau pengaruh setiap elemen terhadap masingmasing tujuan atau kriteria yang setingkat di atasnya. Perbandingan dilakukan berdasarkan judgment dari pengambil keputusan dengan menilai tingkat kepentingan suatu elemen dibandingkan terhadap elemen yang lainnya.

4) Melakukan perbandingan berpasangan sehingga diperoleh judgment seluruhnya $n[(n-$ 1)/2] buah, dengan $n$ adalah banyaknya elemen yang dibandingkan.

5) Menghitung nilai eigen dan menguji konsistensinya. Jika tidak konsisten maka pengambilan data diulangi.

6) Mengulangi langkah 3, 4, dan 5 untuk seluruh tingkat hirarki.

7) Menghitung vektor eigen dari setiap matriks perbandingan berpasangan. Nilai vektor eigen merupakan bobot setiap elemen. Langkah ini untuk mensintesis judgment dalam penentuan prioritas elemen-elemen pada tingkat hirarki terendah sampai pencapaian tujuan.

8) Memeriksa konsistensi hirarki. Jika nilainya lebih dari 10 persen maka penilaian data judgment harus diperbaiki.

\section{Metode weighted average}

Metode weighted average adalah metode dengan pengambilan nilai rata-rata yang didasarkan kepada perhitungan rata-rata dengan memberikan bobot pada masing-masing nilai yang akan diambil nilai rata-ratanya. Bobot masing masing tidak sama, jika semua bobot adalah sama maka perhitungannya merupakan rata-rata aritmatik biasa.

Perhitungan rata-rata dengan metode ini adalah dengan sedikit penambahan pada perhitungan bobotnya. Hampir sama dengan perhitungan ratarata aritmatika biasa. Elemen data yang ada diperhitungkan bobotnya terlebih dahulu, dimana data yang memiliki bobot lebih banyak akan lebih berpengaruh daripada data dengan bobot lebih sedikit. Dengan ketentuan bobot tidak boleh negatif, beberapa diantaranya mungkin nol, namun tidak mungkin jika semua bobotnya nol, karena jika terjadi demikian maka perhitungan tidak mungkin dapat dilakukan. Metode ini banyak digunakan pada analisa system data, perhitungan differensial dan perhitungan kalkulus integral

Secara umum perhitungan metode weighted average dapat dilakukan terhadap data yang ada isinya, $\{x 1, x 2, x 3, \ldots, x n\}$, dengan menggunakan bobot, $\{w 1, w 2, w 3, \ldots, w n\}$, untuk memperoleh rata-rata dengan rumusan sebagai berikut.

$\bar{x}=\frac{w_{1} \cdot x_{1}+w_{2} \cdot x_{2}+w_{3} \cdot x_{3}+\cdots+w_{n} \cdot x_{n}}{w_{1}+w_{2}+w_{3}+\cdots+w_{n}}$

Aturan penggunaan variabel/kelengkapan yang harus diperhatikan pada tiap elemen data dan bobot:

- $\{$ wili $=1,2, \ldots ., n\}>0$

w adalah pembobotan, atas dasar preference (ketertarikan/pilihan yang disukai) pembuat keputusan namun dalam hal ini menggunakan hasil kuesioner.

- Pada kondisi tertentu dimana bobot dinormalisasi sehingga diperoleh jumlah bobot keseluruhan sama dengan satu, maka rumusan diatas dapat menjadi lebih ringkas menjadi

$$
\bar{x}=\sum_{i=1}^{n} w_{i} \cdot x_{i}
$$

\section{Variabel penelitian}

Variabel dalam penelitian ini berdasarkan peraturan, SNI dan pedoman terkait pembangunan embung. Untuk menentukan prioritas, masingmasing variabel diuraikan dalam bentuk interval kelas dan pemberian nilai/score dari data kualitatif dan kuantitatif masing-masing embung. Panjang interval kelas ditentukan dengan membagi range (R) dengan banyaknya kelas yang akan dibuat (K). Dimana range $(\mathrm{R})$ didapatkan dengan mengurangi data terbesar dengan data terkecil. Banyaknya kelas didapatkan dengan persamaan

$\mathrm{K}=1+3,33 \log \mathrm{N}$

dimana:

$\mathrm{K}$ = banyaknya kelas yang akan dibuat

$\mathrm{N}=$ banyaknya data.

Pemberian nilai/score ditentukan dengan angka 5 adalah bobot tertinggi dan angka 1 adalah bobot terendah. 
Bima Anjasmoro, Suharyanto, Sri Sangkawati

Analisis Prioritas Pembangunan Embung Metode Cluster Analysis, AHP dan Weighted Average (Studi Kasus: Embung Di Kabupaten Semarang)

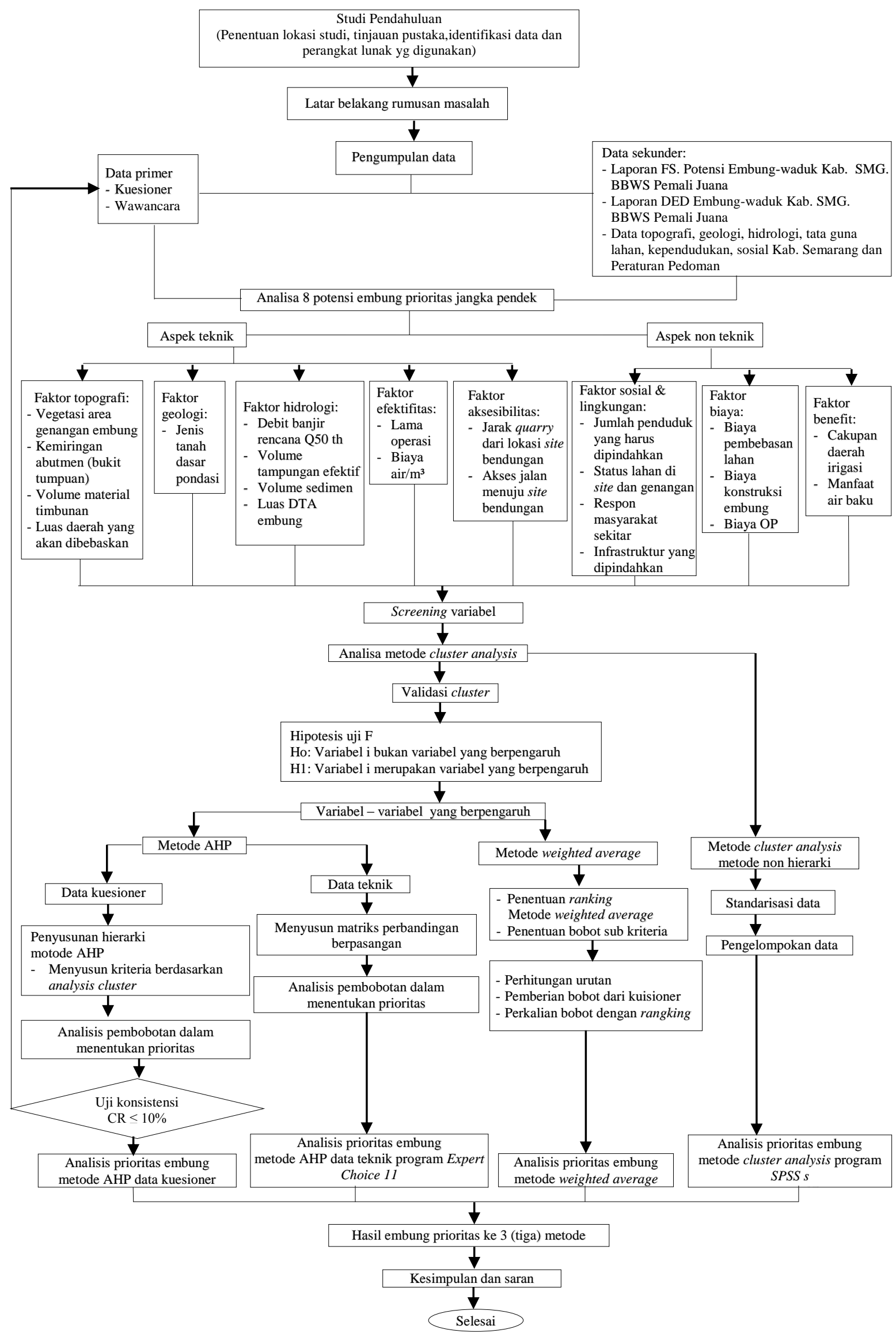

Gambar 2. Alur penelitian 
Variabel-variabel yang akan di analisa adalah:

1) Vegetasi area genangan embung,

2) Kemiringan abutmen bukit tumpuan,

3) Volume material timbunan,

4) Luas daerah yang akan dibebaskan,

5) Jenis tanah dasar pondasi,

6) Debit banjir rencana Q50 th,

7) Volume tampungan efektif,

8) Volume sedimen,

9) Luas DTA embung,

10) Lama operasi,

11) Harga air $/ \mathrm{m}^{3}$,

12) Jarak quarry dari lokasi site bendungan,

13) Akses jalan menuju site bendungan,

14) Jumlah penduduk yang harus dipindahkan,

15) Status lahan di site dan genangan,

16) Respon masyarakat sekitar,

17) Infrastrukutur yang dipindahkan,

18) Biaya pembebasan lahan,

19) Biaya konstruksi,

20) Biaya operasional dan pemeliharaan,

21) Cakupan daerah irigasi dan

22) Manfaat air baku.

\section{Analisis Data dan Pembahasan}

Data yang akan dianalisa adalah data masingmasing embung terhadap masing-masing variabel yang masih bersifat kuantitatif dan kualitatif. Dimana data tersebut telah distandarisasi atau transformasi terhadap variabel yang relevan ke dalam bentuk scoring data variabel. Adapun skala penilaian scoring data memakai skala 1 sampai dengan skala 5. Dimana 5 adalah skala dengan nilai bobot tertinggi, sedangkan 1 adalah skala dengan nilai bobot terendah.

\section{Pemilihan embung prioritas dengan cluster analysis metode non hierarki}

Metode ini dimulai dengan proses penentuan jumlah gerombol terlebih dahulu, dan yang digunakan adalah metode non hierarki. Metode non hierarki digunakan sebagai alternatif metode cluster untuk data dengan ukuran yang besar karena memiliki kecepatan yang lebih tinggi dibandingkan metode hierarki. Mac Queen menyarankan bahwa penggunaan non hierarki untuk menjelaskan algoritma dalam penentuan suatu objek ke dalam cluster tertentu berdasarkan rataan terdekat.

Setelah dilakukan standarisasi data dan telah diperoleh hasil rekapitulasi data masing-masing embung, langkah selanjutnya adalah memasukan data rekapitulasi tersebut ke dalam Program Statistical Package for Social Science (SPSS) 17. Hasil analisa cluster metode non hierarki dari Program SPSS 17 adalah berupa pengelompokan dari masing-masing embung dan jarak masingmasing embung terhadap pusat cluster.

Tabel 1. Rekapitulasi standarisasi data

\begin{tabular}{ccccccccc}
\hline & A1 & A2 & A3 & A4 & A5 & A6 & A7 & A8 \\
\hline $\mathrm{K} 1$ & 2 & 5 & 2 & 2 & 5 & 5 & 3 & 3 \\
$\mathrm{~K} 2$ & 5 & 2 & 2 & 3 & 2 & 3 & 4 & 2 \\
$\mathrm{~K} 3$ & 5 & 1 & 3 & 5 & 5 & 4 & 4 & 5 \\
$\mathrm{~K} 4$ & 4 & 5 & 5 & 4 & 3 & 2 & 5 & 4 \\
$\mathrm{~K} 5$ & 5 & 1 & 5 & 5 & 3 & 1 & 1 & 1 \\
$\mathrm{~K} 6$ & 2 & 2 & 4 & 3 & 2 & 3 & 5 & 3 \\
$\mathrm{~K} 7$ & 3 & 5 & 4 & 4 & 1 & 2 & 1 & 1 \\
$\mathrm{~K} 8$ & 2 & 3 & 2 & 3 & 5 & 3 & 5 & 1 \\
$\mathrm{~K} 9$ & 2 & 1 & 5 & 4 & 3 & 1 & 2 & 2 \\
$\mathrm{~K} 10$ & 2 & 5 & 2 & 2 & 1 & 3 & 1 & 1 \\
$\mathrm{~K} 11$ & 5 & 5 & 3 & 4 & 1 & 1 & 1 & 1 \\
$\mathrm{~K} 12$ & 5 & 3 & 3 & 3 & 3 & 3 & 3 & 1 \\
$\mathrm{~K} 13$ & 3 & 4 & 3 & 3 & 3 & 3 & 3 & 4 \\
$\mathrm{~K} 14$ & 5 & 5 & 5 & 4 & 5 & 5 & 5 & 4 \\
$\mathrm{~K} 15$ & 4 & 2 & 4 & 4 & 3 & 4 & 4 & 4 \\
$\mathrm{~K} 16$ & 4 & 5 & 4 & 4 & 4 & 5 & 5 & 4 \\
$\mathrm{~K} 17$ & 5 & 1 & 5 & 1 & 5 & 5 & 5 & 1 \\
$\mathrm{~K} 18$ & 3 & 5 & 4 & 4 & 3 & 1 & 3 & 4 \\
$\mathrm{~K} 19$ & 4 & 1 & 3 & 5 & 4 & 4 & 4 & 4 \\
$\mathrm{~K} 20$ & 3 & 1 & 2 & 1 & 4 & 4 & 4 & 5 \\
$\mathrm{~K} 21$ & 3 & 5 & 2 & 3 & 2 & 2 & 3 & 2 \\
$\mathrm{~K} 22$ & 2 & 2 & 5 & 5 & 2 & 3 & 5 & 1 \\
\hline $\mathrm{K}$ & &
\end{tabular}

Keterangan:

$\mathrm{K} 1$ = vegetasi area genangan;

$\mathrm{K} 2$ = kemiringan abutmen;

$\mathrm{K} 3$ = volume material timbunan;

$\mathrm{K} 4$ = luas daerah pembebasan;

$\mathrm{K} 5=$ jenis tanah dasar pondasi;

$\mathrm{K} 6=\mathrm{Q}$ rencana;

$\mathrm{K} 7$ = volume tampungan aktif;

$\mathrm{K} 8$ = volume sedimentasi;

K9 = luas DTA;

$\mathrm{K} 10$ = lama operasi;

$\mathrm{K} 11$ = harga air/ $\mathrm{m}^{3}$;

$\mathrm{K} 12$ = jarak quarry ke site;

$\mathrm{K} 13$ = akses jalan menuju site;

$\mathrm{K} 14$ = jumlah penduduk yang dipindahkan;

$\mathrm{K} 15$ = status lahan di site dan genangan;

$\mathrm{K} 16$ = respon masyarakat sekitar;

$\mathrm{K} 17$ = infrastruktur yang dipindahkan;

$\mathrm{K} 18$ = biaya pembebasan lahan;

K19 = biaya konstruksi;

K20 = biaya operasi dan pemeliharaan;

$\mathrm{K} 21$ = cakupan daerah irigasi

$\mathrm{K} 22$ = manfaat air baku.

Tabel 2. Tabel jarak embung terhadap pusat cluster

\begin{tabular}{clcc}
\hline No. & \multicolumn{1}{c}{ Nama embung } & QCL_1 & QCL_2 \\
\hline A1 & Embung Dadapayam & 3 & 4,589 \\
A2 & Embung Mluweh & 2 & 0,000 \\
A3 & Embung Lebak & 3 & 3,816 \\
A4 & Embung Pakis & 3 & 4,308 \\
A5 & Embung Jatikurung & 1 & 3,415 \\
A6 & Embung Gogodalem & 1 & 3,606 \\
A7 & Embung Kandangan & 3 & 5,706 \\
A8 & Embung Ngrawan & 1 & 4,619 \\
\hline
\end{tabular}


Bima Anjasmoro, Suharyanto, Sri Sangkawati

Analisis Prioritas Pembangunan Embung Metode Cluster Analysis, AHP dan Weighted Average

(Studi Kasus: Embung Di Kabupaten Semarang)

Tabel 3. Matriks perbandingan berpasangan kriteria terhadap tujuan

\begin{tabular}{|c|c|c|c|c|c|c|c|c|c|c|c|c|}
\hline & K1 & K2 & K3 & K4 & K5 & K6 & K7 & K8 & K9 & K10 & K11 & K12 \\
\hline K1 & 1,000 & 2,690 & 0,386 & 0,771 & 0,430 & 0,865 & 2,122 & 0,335 & 0,489 & 1,820 & 1,093 & 0,393 \\
\hline $\mathrm{K} 2$ & 0,372 & 1,000 & 0,627 & 0,779 & 0,792 & 0,578 & 1,000 & 0,541 & 1,000 & 1,000 & 1,364 & 0,590 \\
\hline K3 & 2,589 & 1,594 & 1,000 & 2,073 & 2,455 & 1,377 & 2,532 & 1,000 & 1,000 & 1,828 & 4,138 & 1,000 \\
\hline K4 & 1,297 & 1,283 & 0,482 & 1,000 & 1,000 & 1,000 & 1,093 & 1,062 & 1,000 & 1,000 & 1,000 & 1,000 \\
\hline K5 & 2,326 & 1,263 & 0,407 & 1,000 & 1,000 & 1,000 & 2,552 & 0,455 & 2,293 & 2,304 & 1,000 & 2,333 \\
\hline K6 & 1,156 & 1,730 & 0,726 & 1,000 & 1,000 & 1,000 & 0,498 & 0,399 & 1,000 & 1,000 & 1,000 & 1,000 \\
\hline K7 & 1,000 & 1,000 & 0,395 & 0,915 & 0,392 & 2,007 & 1,000 & 1,790 & 1,000 & 1,000 & 1,135 & 0,473 \\
\hline K8 & 1,849 & 1,849 & 1,000 & 0,942 & 2,196 & 2,504 & 0,559 & 1,000 & 2,539 & 2,422 & 2,541 & 0,272 \\
\hline K9 & 2,047 & 1,000 & 1,000 & 1,000 & 0,436 & 1,000 & 1,000 & 0,394 & 1,000 & 1,000 & 0,406 & 0,632 \\
\hline K10 & 0,549 & 1,000 & 0,547 & 1,000 & 0,434 & 1,000 & 1,000 & 0,413 & 1,000 & 1,000 & 0,385 & 1,427 \\
\hline K11 & 0,915 & 0,733 & 0,242 & 1,000 & 1,000 & 1,000 & 0,881 & 0,500 & 2,462 & 2,600 & 1,000 & 1,000 \\
\hline K12 & 2,544 & 1,696 & 1,000 & 1,000 & 0,429 & 1,000 & 2,114 & 3,681 & 1,582 & 0,701 & 1,000 & 1,000 \\
\hline
\end{tabular}

QCL 1 adalah nomor cluster dari keberadaan embung, dan QCL_2 adalah jarak antara objek/ embung dengan pusat cluster. Dengan demikian dapat ditafsirkan sebagai berikut:

1.Cluster-1 : berisikan Embung Jatikurung, Embung Gogodalem dan Embung Ngrawan dengan masing-masing jarak terhadap pusat cluster - 1 adalah 3,415; 3,606 dan 4,619.

2.Cluster-2 : bersikan Embung Mluweh dengan jarak terhadap pusat cluster - 2 adalah 0,000

3.Cluster-3 : berisikan Embung Dadapayam, Embung Lebak, Embung Pakis dan Embung Kandangan dengan masing-masing jarak terhadap pusat cluster - 3 adalah 4,589; 3,816; 4,308 dan 5,706.

Untuk melihat apakah variabel-variabel yang telah membentuk cluster tersebut merupakan variabel yang berpengaruh dalam pembangunan embung maka perlu di uji validasinya dengan menggunakan uji Hipotesis Varians. Uji ini dipakai untuk mengetahui nilai relatif masingmasing variabel dan biasa lebih efektif untuk menguji jumlah variabel dan populasi lebih dari satu.

Karena nilai $\mathrm{F}$ hitung dari ke-22 (dua puluh dua) variabel terdapat 12 (dua belas) yang bernilai > dari 2,747 yaitu:

1) Vegetasi area genangan embung,

2) Volume material timbunan,

3) Luas daerah yang akan dibebaskan,

4) Volume tampungan efektif,

5) Lama operasi,

6) Harga air $/ \mathrm{m}^{3}$,

7) Akses jalan masuk menuju site bendungan,

8) Status lahan di site dan genangan,

9) Biaya konstruksi embung,

10) Biaya OP,

11) Cakupan daerah irigasi,

12) Manfaat air baku.
12 (dua belas) variabel tersebut merupakan variabel yang berpengaruh dalam pembangunan embung.

Pemilihan embung prioritas metode AHP berdasarkan data kuesioner

Proses pengambilan keputusan dengan metode AHP bertujuan untuk memberikan penilaian bagi faktor terukur dan tidak terukur serta sub faktor yang mempengaruhi keputusan pemilihan embung prioritas. Penilaian perbandingan diberikan berdasarkan hasil kuesioner untuk kriteria terhadap tujuan dan alternatif terhadap kriteria. Hasil akhir AHP berupa suatu rangking berdasarkan penilaian bobot prioritas dari setiap alternatif yang tersedia.

\section{Perhitungan pembobotan kriteria terhadap tujuan}

Dari hasil kuisioner diperoleh hasil perbandingan dalam bentuk matriks perbandingan berpasangan antara kriteria-kriteria yang digunakan dalam penelitian ini sebagaimana pada Tabel 3.

Untuk model AHP matrik perbandingan dapat diterima jika nilai ratio konsisten tidak lebih dari $10 \%$ atau sama dengan 0,1 . Karena nilai $\mathrm{CR}=$ $0,0011 \leq 0,1$ maka matriks perbandingan dapat diterima/konsisten.

Tabel 4. Rekapitulasi bobot kriteria

\begin{tabular}{clr}
\hline Kode & \multicolumn{1}{c}{ Kriteria } & \multicolumn{1}{c}{ Bobot } \\
\hline K1 & Vegetasi area genangan embung & $6,950 \%$ \\
K2 & Volume material timbunan & $6,319 \%$ \\
K3 & Luas daerah yang akan dibebaskan & $12,228 \%$ \\
K4 & Volume tampungan efektif & $8,500 \%$ \\
K5 & Lama operasi & $9,431 \%$ \\
K6 & Harga air/m ${ }^{3}$ & $7,709 \%$ \\
K7 & Akses jalan masuk menuju site bendungan & $7,593 \%$ \\
K8 & Status lahan di site dan genangan & $9,284 \%$ \\
K9 & Biaya konstruksi embung & $7,543 \%$ \\
K10 & Biaya OP & $6,904 \%$ \\
K11 & Cakupan daerah irigasi & $6,862 \%$ \\
K12 & Manfaat air baku & $10,678 \%$ \\
\hline
\end{tabular}




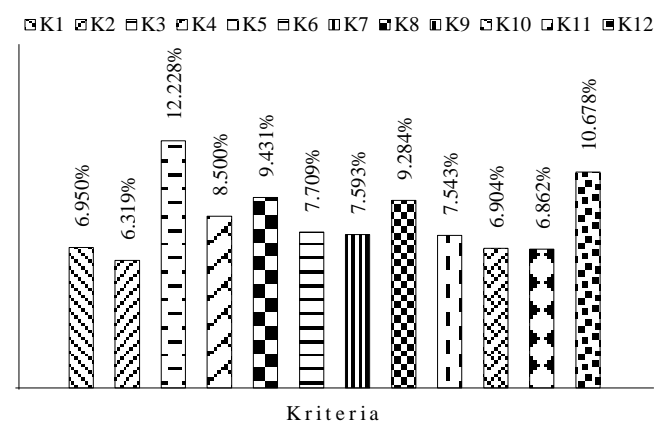

Perhitungan pembobotan alternatif terhadap kriteria

Proses perhitungan pembobotan alternatif terhadap kriteria adalah dengan membandingkan beberapa alternatif terhadap masing-masing kriteria. Tahapan perhitungannya sama dengan pembobotan kriteria terhadap tujuan.

Gambar 3. Grafik bobot kriteria terhadap tujuan

Tabel 5. Rekapitulasi bobot alternatif terhadap kriteria

\begin{tabular}{|c|c|c|c|c|c|c|c|c|c|c|c|c|}
\hline & K1 & K2 & K3 & K4 & K5 & K6 & K7 & K8 & K9 & K10 & K11 & K12 \\
\hline A1 & $0,334 \%$ & $1,353 \%$ & $0,925 \%$ & $0,558 \%$ & $0,925 \%$ & $1,941 \%$ & $0,647 \%$ & $1,589 \%$ & $1,257 \%$ & $1,335 \%$ & $0,913 \%$ & $1,043 \%$ \\
\hline A3 & $0,348 \%$ & $0,382 \%$ & $2,251 \%$ & $2,044 \%$ & $1,171 \%$ & $1,207 \%$ & $0,644 \%$ & $1,428 \%$ & $0,462 \%$ & $0,342 \%$ & $0,578 \%$ & $2,505 \%$ \\
\hline A5 & $1,531 \%$ & $0,795 \%$ & $0,750 \%$ & $1,037 \%$ & $0,680 \%$ & $0,575 \%$ & $0,641 \%$ & $0,411 \%$ & $1,467 \%$ & $0,695 \%$ & $0,383 \%$ & $0,619 \%$ \\
\hline A6 & $1,556 \%$ & $0,521 \%$ & $0,566 \%$ & $0,551 \%$ & $1,809 \%$ & $0,695 \%$ & $0,622 \%$ & $1,349 \%$ & $0,826 \%$ & $1,556 \%$ & $0,604 \%$ & $1,275 \%$ \\
\hline A7 & $0,733 \%$ & $0,690 \%$ & $1,952 \%$ & $1,557 \%$ & $0,357 \%$ & $0,442 \%$ & $0,631 \%$ & $1,347 \%$ & $0,579 \%$ & $0,441 \%$ & $0,983 \%$ & $1,647 \%$ \\
\hline
\end{tabular}

Keterangan :

A1 = Embung Dadapayam

A2 = Embung Mluweh

A3 = Embung Lebak

A4 = Embung Pakis

A5 = Embung Jatikurung

A6 = Embung Gogodalem

A7 = Embung Kandangan

A8 = Embung Ngrawan

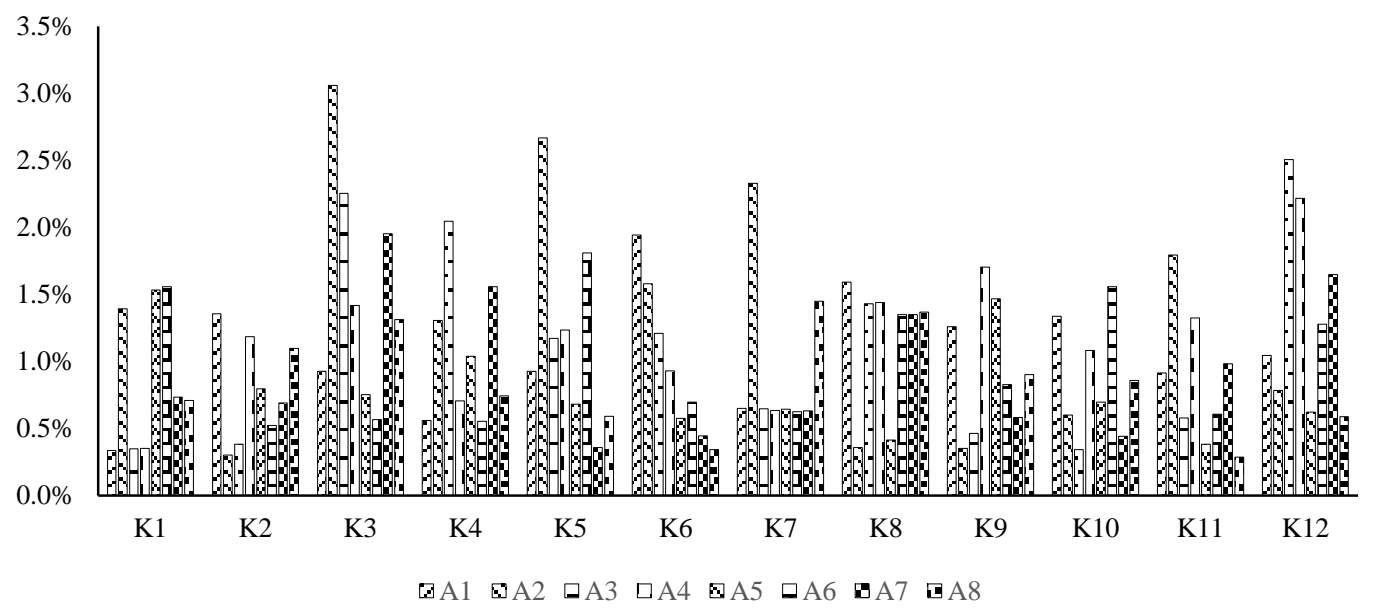

Gambar 4. Grafik bobot alternatif terhadap kriteria

Tabel 6. Jumlah bobot alternatif

\begin{tabular}{llc}
\hline & \multicolumn{1}{c}{ Embung pilihan } & Bobot \\
\hline A1 & Embung Dadapayam & $12,820 \%$ \\
A2 & Embung Mluweh & $16,510 \%$ \\
A3 & Embung Lebak & $13,365 \%$ \\
A4 & Embung Pakis & $14,208 \%$ \\
A5 & Embung Jatikurung & $9,585 \%$ \\
A7 & Embung Gogodalem & $11,929 \%$ \\
A8 & Embung Kandangan & $11,357 \%$ \\
A9 & Embung Ngrawan & $10,227 \%$ \\
\hline
\end{tabular}

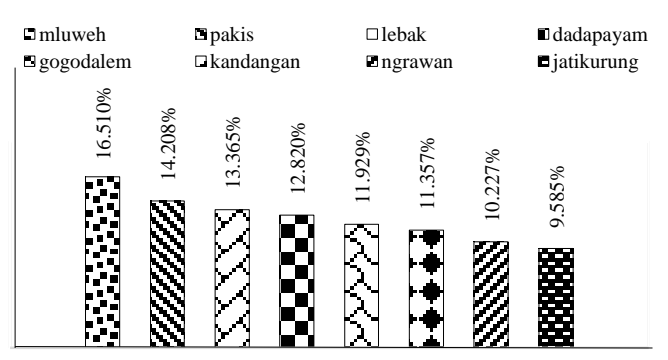

Gambar 5. Grafik rangking prioritas embung 
Bima Anjasmoro, Suharyanto, Sri Sangkawati

Analisis Prioritas Pembangunan Embung Metode Cluster Analysis, AHP dan Weighted Average

(Studi Kasus: Embung Di Kabupaten Semarang)

Pemilihan embung prioritas metode AHP berdasarkan data teknik

Proses pengambilan keputusan dengan metode ini adalah dengan membandingkan data teknik dari masing-masing alternatif terhadap masing-masing kriteria. Nilai dari tingkat kepentingan ditentukan dengan membagi interval dari hasil matriks perbandingan masing-masing data. Pembagian interval dibagi dari tingkat kepentingan 1 (satu) sampai dengan 9 (sembilan). Hasil akhir metode ini berupa rangking yang berdasarkan penilaian bobot dari masing-masing alternatif.

\section{Perhitungan pembobotan alternatif terhadap kriteria}

Proses perhitungan pembobotan alternatif terhadap kriteria adalah dengan membandingkan beberapa alternatif terhadap masing-masing kriteria. Tahapan perhitungannya sama dengan pembobotan kriteria terhadap tujuan.

Tabel 7. Rekapitulasi bobot alternatif terhadap kriteria

\begin{tabular}{ccccccccccccc}
\hline & K1 & K2 & K3 & K4 & K5 & K6 & K7 & K8 & K9 & K10 & K11 & K12 \\
\hline A1 & 0,020 & 0,271 & 0,061 & 0,141 & 0,127 & 0,136 & 0,049 & 0,227 & 0,157 & 0,103 & 0,139 & 0,052 \\
A2 & 0,267 & 0,042 & 0,347 & 0,230 & 0,240 & 0,222 & 0,106 & 0,105 & 0,014 & 0,062 & 0,305 & 0,039 \\
A3 & 0,020 & 0,065 & 0,242 & 0,147 & 0,127 & 0,143 & 0,060 & 0,129 & 0,025 & 0,079 & 0,104 & 0,234 \\
A4 & 0,020 & 0,187 & 0,102 & 0,175 & 0,127 & 0,209 & 0,060 & 0,129 & 0,346 & 0,074 & 0,147 & 0,234 \\
A5 & 0,267 & 0,124 & 0,028 & 0,066 & 0,094 & 0,062 & 0,060 & 0,026 & 0,235 & 0,163 & 0,049 & 0,071 \\
A6 & 0,267 & 0,094 & 0,016 & 0,125 & 0,169 & 0,116 & 0,060 & 0,129 & 0,070 & 0,117 & 0,064 & 0,122 \\
A7 & 0,070 & 0,094 & 0,158 & 0,066 & 0,028 & 0,059 & 0,060 & 0,129 & 0,048 & 0,172 & 0,144 & 0,234 \\
A8 & 0,070 & 0,124 & 0,046 & 0,051 & 0,088 & 0,053 & 0,543 & 0,129 & 0,105 & 0,230 & 0,048 & 0,014 \\
\hline
\end{tabular}

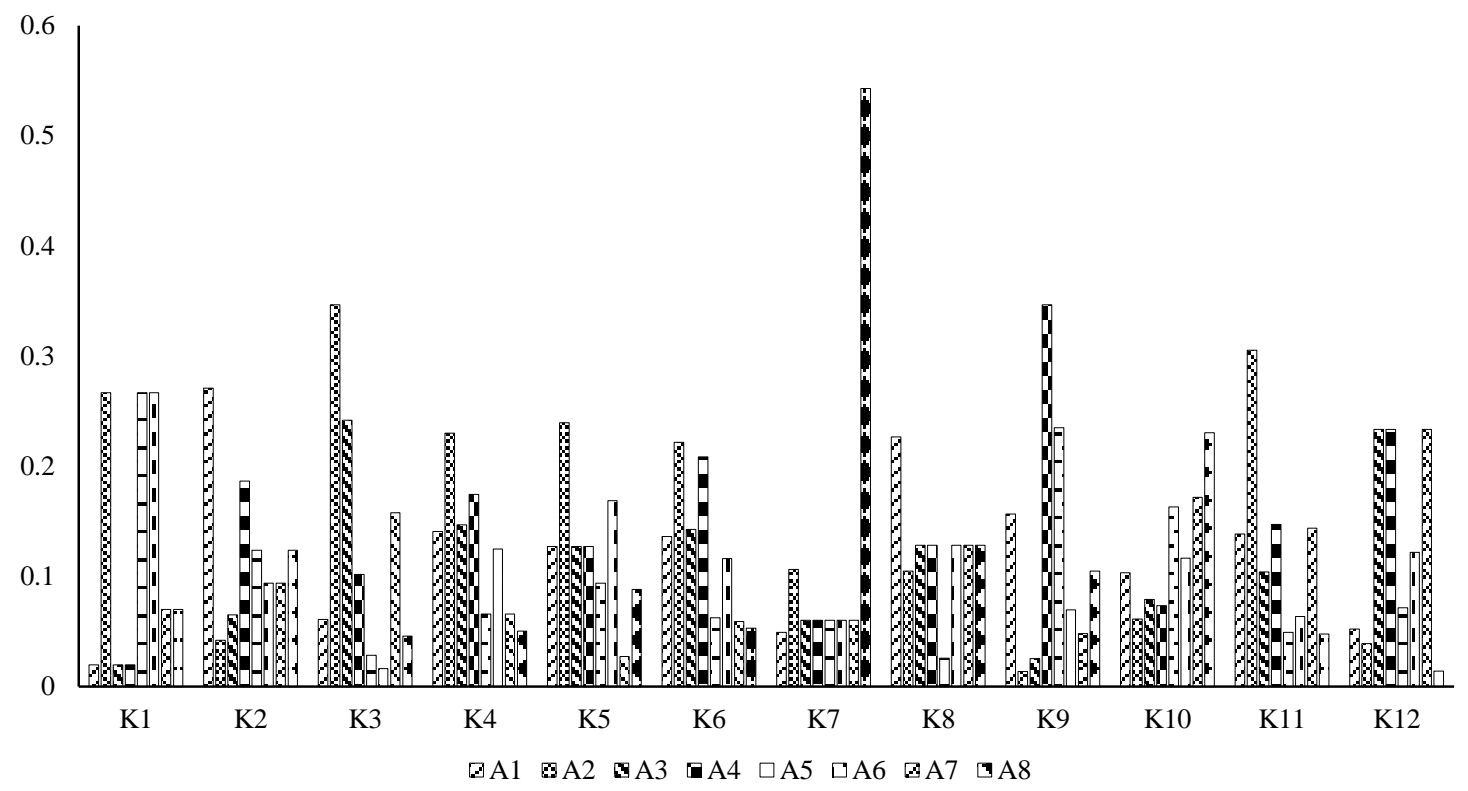

Gambar 6. Grafik bobot alternatif terhadap kriteria

Tabel 8. Jumlah bobot alternatif

\begin{tabular}{llc}
\hline & \multicolumn{1}{c}{ Embung pilihan } & Bobot \\
\hline A1 & Embung Dadapayam & $12,820 \%$ \\
A2 & Embung Mluweh & $16,510 \%$ \\
A3 & Embung Lebak & $13,365 \%$ \\
A4 & Embung Pakis & $14,208 \%$ \\
A5 & Embung Jatikurung & $9,585 \%$ \\
A7 & Embung Gogodalem & $11,929 \%$ \\
A8 & Embung Kandangan & $11,357 \%$ \\
A9 & Embung Ngrawan & $10,227 \%$ \\
\hline
\end{tabular}

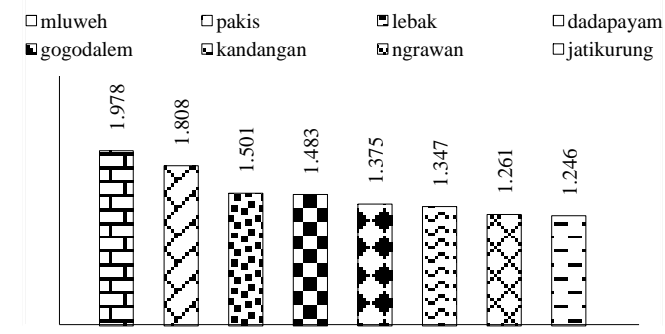

Gambar 7. Grafik rangking prioritas embung 
Pemilihan embung prioritas dengan metode weighted average

Bobot kriteria yang digunakan adalah hasil kuesioner yang telah dianalisa menggunakan metode AHP data kuesioner. Pembobotan untuk alternatif pilihan lokasi embung dilakukan terhadap seluruh kriteria yang ada. Pembobotan alternatif untuk kriteria dilakukan berdasarkan data sekunder dari penelitian ini. Dimana data masingmasing embung diberikan rangking sesuai dengan nilai scoring/standarisasi data dari pembahasan sebelumnya. Dimana masing-masing alternatif terhadap kriteria dengan semakin besar nilainya maka semakin besar nilai tingkat kepentingannya. Nilai rangking alternatif tersebut kemudian dikalikan dengan nilai kepentingan kriteria sehingga diperoleh nilai kombinasi yang kemudian dijumlahkan untuk memperoleh nilai keseluruhan. Hasil nilai akhir inilah yang nantinya akan dibandingkan antara satu alternatif dengan alternatif lainnya sebagai dasar penentuan pemiilihan embung prioritas.

Tabel 9. Jumlah bobot alternatif

\begin{tabular}{llc}
\hline & \multicolumn{1}{c}{ Kriteria } & Nilai kombinasi \\
\hline A1 & Embung Dadapayam & 2,674 \\
A2 & Embung Mluweh & 2,869 \\
A3 & Embung Lebak & 2,525 \\
A4 & Embung Pakis & 2,757 \\
A5 & Embung Jatikurung & 2,095 \\
A6 & Embung Gogodalem & 2,276 \\
A7 & Embung Kandangan & 2,230 \\
A8 & Embung Ngrawan & 2,247 \\
\hline
\end{tabular}

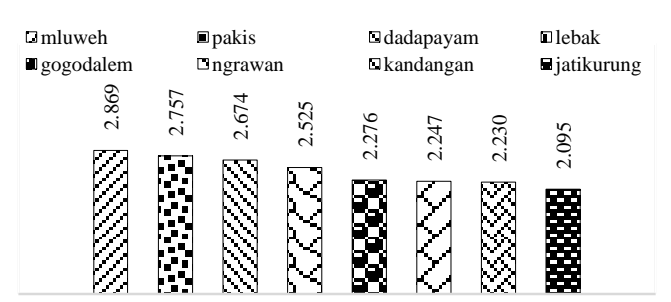

Gambar 8. Grafik rangking prioritas embung

Tabel 10. Hasil embung prioritas metode cluster analysis, AHP data kuesioner, data teknik dan weighted average

\begin{tabular}{|c|c|c|c|c|}
\hline \multirow{2}{*}{ Embung pilihan } & \multicolumn{2}{|c|}{ Metode AHP } & \multirow{2}{*}{$\begin{array}{c}\text { Metode } \\
\text { Weighted average }\end{array}$} & \multirow{2}{*}{$\begin{array}{c}\text { Metode } \\
\text { Analysis cluster }\end{array}$} \\
\hline & Data kuesioner & Data teknik & & \\
\hline A1 Embung Dadapayam & 4 & 4 & 3 & Cluster-1 Jatikurung \\
\hline A2 Embung Mluweh & 1 & 1 & 1 & Gogodalem \\
\hline A3 Embung Lebak & 3 & 6 & 4 & Ngrawan \\
\hline A4 Embung Pakis & 2 & 2 & 2 & Cluster - 2 \\
\hline A5 Embung Jatikurung & 8 & 8 & 8 & Cluster - 3 Dadapayam \\
\hline A6 Embung Gogodalem & 5 & 5 & 5 & Lebak \\
\hline A7 Embung Kandangan & 6 & 7 & 7 & Pakis \\
\hline A8 Embung Ngrawan & 7 & 3 & 6 & Kandangan \\
\hline
\end{tabular}

Hasil embung prioritas metode analysis cluster, AHP data kusioner, data teknik dan weighted average

Dari hasil analisa yang telah dilakukan dapat diketahui hasil perbedaan penentuan prioritas embung antara ke 3 (tiga) metode tersebut.

\section{Kesimpulan}

Dari hasil analisa yang telah dilakukan dalam penelitian ini, dapat diperoleh beberapa kesimpulan sebagai berikut:

1. Varibel - variabel yang berpengaruh dalam pembangunan embung dengan menggunakan metode cluster analysis metode non hierarki adalah: 1) Vegetasi area genangan embung $(7,652), 2)$ Volume material timbunan $(7,744)$, 3) Luas daerah yang akan dibebaskan $(4,167)$, 4) Volume tampungan efektif $(4,203)$, 5) Lama operasi $(6,921), 6)$ Harga air $\left./ \mathrm{m}^{3}(4,321), 7\right)$ Akses jalan masuk menuju site bendungan $(3,125), 8)$ Status lahan di site dan genangan $(12,031), 9)$ Biaya konstruksi embung $(9,844)$, 10) Biaya OP (4,559), 11) Cakupan daerah irigasi $(22,500)$ dan 12) Manfaat air baku $(2,893)$.

2. Berdasarkan perhitungan dengan metode cluster analysis, AHP data kuesioner, data teknik dan weighted average, prioritas pembangunan embung jangka pendek adalah : 1) Embung Mluweh $(0,165), 2)$ Embung Pakis (0,142), 3) Embung Lebak (0,134), 4) Embung Dadapayam (0,128), 5) Embung Gogodalem (0,119), 6) Embung Kandangan (0,114), 7) Embung Ngrawan $(0,102)$ dan 8) Embung Jatikurung $(0,096)$. 


\section{Saran}

Dari hasil analisa yang telah dilakukan dengan kesimpulan tersebut diatas, dapat disampaikan beberapa saran sebagai berikut:

1. Dalam penelitian ini pemberian interval kelas untuk mendapatkan bobot pada semua variabel belum seragam. Artinya ada beberapa variabel yang mempunyai interval kelas berbeda. Disarankan untuk penelitian selanjutnya menggunakan interval kelas yang seragam dengan tetap memberikan sumber penjabaran interval kelas dari masing-masing variabel yang akan dianalisa.

2. Untuk hasil yang lebih optimal, dalam penentuan data yang mengandalkan penilaian responden (melalui wawancara/kuisioner), dapat dilakukan penambahan jumlah responden atau para ahli dengan sumber yang semakin luas guna menjaga konsistensi data.

3. Untuk mendapatkan hasil yang berbeda, dalam proses standarisasi data pada metode cluster analysis dapat dilakukan dengan mencari standar yang lebih baku atau dengan standarisasi/transformasi pada program SPSS.

4. Pada penelitian ini pemberian nilai skala perbandingan pada metode AHP data teknik menggunakan patokan skala 1-9 sesuai dengan metode AHP data kuesioner. Disarankan untuk penelitian selanjutnya bisa menggunakan patokan skala perbandingan dengan membagi interval kelas pada nilai perbandingan terbesar dan terkecil.

\section{Daftar Pustaka}

Bima Anjasmoro, 2016. Analisis Prioritas Pembangunan Embung Metode Cluster Analysis, Analytical Hierarchy Process dan Weighted Average Studi Kasus Embung di Kabupaten Semarang, Tesis Magister Teknik Sipil Program Pasca Sarjana Universitas Diponegoro Semarang.

Harinaldi, 2005. Prinsip-prinsip Statistik untuk Teknik dan Sains, Erlangga, Jakarta.
ICOLD (International Commission on Large Dam), 2014. Small Dams Design, Surveillance and Rehabilitation, Bulletins 157-france.

Kodoatie, Robert J., Sjarief, Roestam, 2005. Pengelolaan Sumber Daya Air Terpadu, Andi Offset, Yogyakarta.

Latifah, Siti, 2005. Prinsip-prinsip Dasar Analytical Hierarchy Process, e-USU Reposritory, Universitas Sumatera Utara.

Mac Queen. J., 1967. Some methods for classification and analysis of multivariate observations, Proceedings of the Fifth Berkeley Symposium on Mathematical Statistics and Probability, Volume 1: Statistics, 281--297, University of California Press, Berkeley, Calif.

Peraturan Pemerintah Republik Indonesia Nomor 37 Tahun 2010 tentang Bendungan.

Robinson Sitepu, 2011. Analisis Cluster terhadap Tingkat Pencemaran Udara pada Sektor Industri di Sumatera Selatan, Jurnal FMIPA, Volume 14 Nomor 3 (A), Universitas Sriwijaya.

\section{RSNI T-01-2002 (Tata Cara Desain Tubuh Bendungan Tipe Urugan)}

Saaty, 1983. The Analytic Hierarchy Process; Planning, Priority, Setting, Resource Allocation, University of Pittsburgh.

Sobriyah, 2005. Sistem Pendukung Keputusan pada Penentuan Prioritas Rehabilitasi Jaringan Irigasi di DIY, Gema Teknik Fakultas Teknik Universitas Sebelas Maret, Solo.

Soedibyo, 1998. Teknik Bendungan. Pradnya Paramita, Jakarta.

SNI 03-1724, 1989. Tata Cara Perencanaan Hidrologi dan Hidraulika untuk Bangunan di Sungai.

Suripin, 2002. Pelestarian Sumber Daya Tanah dan Air, Andi Offset, Yogyakarta. 